\title{
Effect of Return on Assets on Firm Value Using Zakat as the Moderating Variable
}

\author{
Dien Triana ${ }^{1}$, Andi Nurul Istiyana ${ }^{1}$, Azwar Anwar ${ }^{2}$, Rasyidah Nadir $^{1}$ \\ \{dientriana@poliupg.ac.id $\left.{ }^{1}\right\}$ \\ Politeknik Negeri Ujung Pandang Makassar ${ }^{1}$ \\ Universitas Negeri Makassar $^{2}$
}

\begin{abstract}
This research aims to test the effect of Return on Assets (ROA) on firm value by using zakat as the moderating variable. Some previous studies used other variables as moderating variable. So far, there is no research yet uses zakat as a moderating variable.The population of this study is all companies listed in the Malaysian Stock Exchange (MSE). The sampling technique used purposive sampling. The samples had to have zakat payment for 5 years. The obtained data were tested using multiple linear regression model and interaction test of Moderate Regression Analysis. The control variables used are Leverage and Market to Book Value of Assets against Firm Value Variable.

The results showed that the ROA variable had a significant positive effect on the firm value (Tobin's Q), while using zakat as moderation variable, ROA has no significant positive effect on the firm value.
\end{abstract}

Keywords: ROA, Firm Value, Zakat

\section{Introduction}

Profitability is a major indicator in measuring company performance. For companies whose main purpose is to make a profit, improving financial performance is very important. In addition, the ratio financial performance ratios during a certain period of time is a valuable basic consideration for investors when investing in an enterprise. Previous research has focused more on the effect of profitability on firm value with differing results. According to Modigliani and Miller [1], the value of a company is determined by the earning power of the company's assets. The level of earning power is determined by two factors, these are: (1) profit margin, which is a comparison of net profit to net sales; and (2) turnover of operating assets or the rate of asset turnover during a given period calculated by dividing net sales by total assets. Greater earning power means more efficient asset turnover and/or higher profit margins. Furthermore, an increase in profit margin can have a positive impact on firm value.

In line with research conducted by Modigliani and Miller, a study by Sucuahi and Cambarihan [2] on the effect of profitability on on the firm value of Diversified Companies in the Philippines found that profitabiltiy has a significant positive effect on firm value. In addition, Handoko [3] found that the profitability that is proxied by Return on Assets (ROA) has a significant positive effect on firm value. However, other research has shown that ROA does not have a significant effect on the value of a company and there may be other indicators that are better able to describe the value of a company [4]. The inconsistency of these results 
shows there are other variables that effect the relationship between ROA and firm value. Therefore, this study includes zakat as a governing variable alongside other variables deemed to significantly effectfirm value. Previous studies conducted by Yuniasih and Wirakusuma (2009)[5], Sari (2012)[4], and Hadianto [6] used Corporate Social Responsibility (CSR) and Good Corporate Governance (GCG) as moderating variables. However, these studies have never accounted for zakat as a moderating variable.

Firm value is the price that a prospective buyer would be willing to pay for a company. Various policies can be taken by management in efforts to increase firm value, such as increasing the fortune of its owners and shareholders reflected in stock price. Wahyudi and Hartini [7]states that the value of the company is the price a prospective buyer would be willing to pay for company if sold. The higher the profitability, the greater the value of the company; in other words, the higher the profitability the lower the systematic risk, as seen in a study by Anwar [8] who found that Return on Equity (ROE) has a significant negative effect on systematic risk. The effect of profitability on firm value is moderated by several factors, among them GCG and CSR [6]. There are no known previous studies that examine the interaction between zakat and profitability or firm value. In addition, a company financial statements in Indonesia do not explicitly state the amount of zakat paid by the company. One possible reason is because there are no rules that require it. Therefore, this study uses companies listed on the Malaysian Stock Exchange as references for its application in Indonesia.

This study aims to examine and analyze the effect of profitability (ROA) on the value of a company both directly and through the mediation of corporate zakat. Therefore, the research problem of this study is understanding how profitability directly effects firm value and how profitability effects firm value with zakat as a moderating variable.

A study by Yuniasih and Wirakusuma [5] showed that CSR was able to moderate the relationship between performance with the value of the company. Similarly, Agustina [9] found that disclosure of CSR significantly effectd the value of a company. This research uses zakat as a moderating variable with the consideration that zakat is commensurate with CSR. Therefore the hypotheses presented in this study are:

H1: ROA has a significant positive effect on firm value.

$\mathrm{H} 2$ : $\quad$ ROA has a significant positive effect on firm value using zakat as a moderating variable.

This research is expected to provide empirical evidence about the effect of company profitability using zakat as a moderating variable on the companies listed on the Malaysian Stock Exchange. This empirical evidence serves as data and support that is scientifically verifiable based on theoretical foundations developed on the topic of the effect of financial performance on firm value using zakat as a moderating variable. This research is also expected to contribute to existing literature on financial management particularly with regard to profitability, zakat, and the firm value. In addition, the results of this study may be used by other parties as reference in accounting, financial and capital market research, especially regarding zakat as a moderator of the effect of profitability on firm value.

The results of the study are expected to form a basis for practitioners, especially investors and management, in making investment decisions or sharia-based financial management. The results of this research are also expected to contribute in strengthening the structure of Islamic finance in a variety of sectors to create a sharia economy based on the principles of fairness and well-being. 


\section{Method}

This research was conducted on the Malaysian Stock Exchange. Variables that were measured include:

1. Dependent Variables. The Dependent Variable used in this study is Firm value (Tobins Q). Tobins $\mathrm{Q}$ is the ratio between market value of equity plus debt with book market value plus debt. According to Herawati [10], firm value measured through Tobins Q is formulated as follows:

\section{Tobins Q = Total Market Value of Firm / Total Asset Value of Firm}

Market Value Equity (MVE) is obtained from the result of multiplying the end-of-year stock price with the number of outstanding shares at the end of the year. Total Asset Value of Firm is the difference between total company assets and total liabilities.

2. Independent Variables. The independent variables in this research are:

a. Profitability Ratio. There are two types of profit ratio, profit in its relationship to sales and profit in its relationship to investment. [11], [12]. This research refers to profits as they relate to investmant, or Return on Equity. ROE is the ratio used to measure the net income earned by a company for the funds it has invested. ROE is also commonly known as self-funded rentability. The greater the ROE ratio better condition the company is in, therefore increasing investor trust. The ROE ratio is formulated as follows:

$$
\text { ROA }=\text { EBITDA/Net Equity }
$$

Notes:

EBITDA = Earning Before Interest, Taxes and

Depreciation

Net Equity = Clean Equity of the Company

b. Zakat. Zakat is a variable that greatly effects investment [13]. Company zakat is a function of investment profits and unprofitable or underperforming assets. Zakat is thus formulated as follows: zakat = total annual zakat/company equity

c. Control Variable. Susanti [14] found that many factors effectfirm value, but the most significant factors include finance risk proxied by rasio, leverage, and Investment Opportunities Set (IOS). IOS is firm value that is dependent on managementdetermined future expenditures that are measurable through market to book value of assets.A model of this can be seen in Figure 1. 


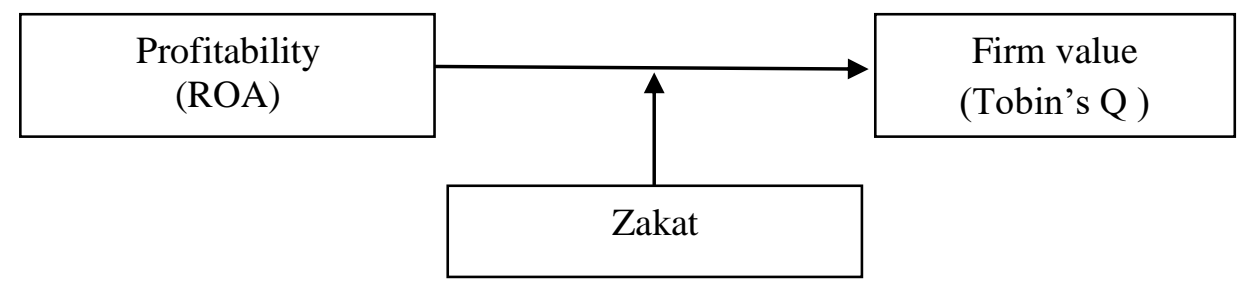

Figure 1. Research Model

This research is a hypothesis test conducted using secondary data sourced from financial reports of companies listed in the Malaysian Stock Exchange. The financial reports of each sample company were analyzed and the total amount of zakat paid was noted. Only data relevant to the variables of this research were taken. The obtained data was then tested with a hypothesis testing model using Multiple Regression Analysis and Moderated Regression Analysis (MRA).

Data was collected using purposive sampling by taking data from the Malaysian Stock Exchange, specifically data for companies that paid zakat that were listed on the stock exchange for the 5-year period of 2011-2015. The data collected was then tested with a hypothesis evaluation model using a Multiple Regression Analysis and Moderated Regression Analysis (MRA). The Multiple Regression Analysis model is as follows:

$$
\text { Yit }=\alpha+\beta 1 X 1 i t+\beta 2 X 2 i t+\beta 3 X 3 i t+\beta 4 X 4 i t+\beta 5 X 1 i t X 2 i t+e
$$

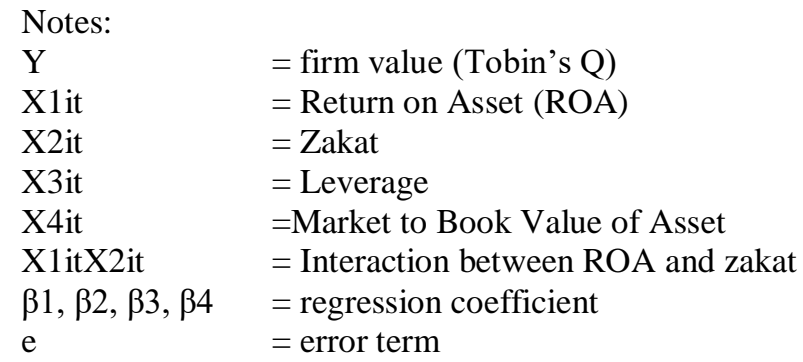

Moderated Regression Analysis (MRA) is a special application of multiple regression analysis where the regression formula contains elements of interaction (product of two or more independents) [15]. The product variable between ROA (X1) and zakat (x2) is a moderating variable because it describes the effect of the moderating variable zakat (X2) on the relationship between ROA (X1) and Tobins' Q (Y). The control variables were Leverage (X3) and Market to Book Value of Asset (X4) in relation to Tobins' Q (Y). Data was analyzed using the software Eviews 9.0. 


\section{Results And Discussion}

Multiple regression analysis yielded an Adjusted R2 of 0.959 or $95.9 \%$ effect of tested independent variable on the dependent variable (Tobins' Q) with a significance of $\alpha<1 \%$. ROA or company performance had a significant positive effect on firm value, and the hypothesis that company performance had a significant positive effect on firm value can thus

VARIABLE

EV

B

t-Hit

Sig.

be accepted. Therefore, empirically, company performance (ROA) had a significant effect on the firm value of companies listed on the Malaysian Stock Exchange that paid zakat. Likewise, the control variables Leverage and MBV also had significant effect Only zakat had a significance of $\alpha<5 \%$. These results can be seen in Table 1 .

Table 1. Results of Regression on Company Performance Effect on Firm value

\begin{tabular}{|c|c|c|c|c|}
\hline VARIABLE & EV & B & t-Hit & Sig. \\
\hline Constant & + & 0,263758 & 2,594057 & 0,0116 \\
\hline ROA & + & 4,546267 & 3,624457 & 0,0005 \\
\hline LEVERAGE & - & 0,043872 & 4,002188 & 0,0002 \\
\hline MBV & + & 0,109792 & 41,30693 & 0,0000 \\
\hline ZAKAT & + & 73,59316 & 2,638907 & 0,0103 \\
\hline Signifikan F & & & & 0.000000 \\
\hline F Hitung & & & & 429,9602 \\
\hline Adj. $\mathrm{R}^{2}$ & & & & 0,959191 \\
\hline $\mathrm{N}$ & & & & 74 \\
\hline
\end{tabular}

The results of the data processing in Table 2 further show that only two independent variables have significant effect and are in accordance with the expectation of the dependent variable, namely the variable Leverage and Market to Book Value. ROA, ZAKAT dan the moderating variable (Zakat*ROA) did not significantly effect the variable independent (Tobins' Q). The level of effect of the independent variable of $95.2 \%$ based on the results shown from the value of the adjusted R2 with a level of significance of under $1 \%$. Based on the results of the data processing it is believed that of all independent variables Leverage (LEV) and Market to Book Value (MBV) had the most significant effect on firm value (Tobins' Q), whereas ROA and zakat did not have a significant effect. 


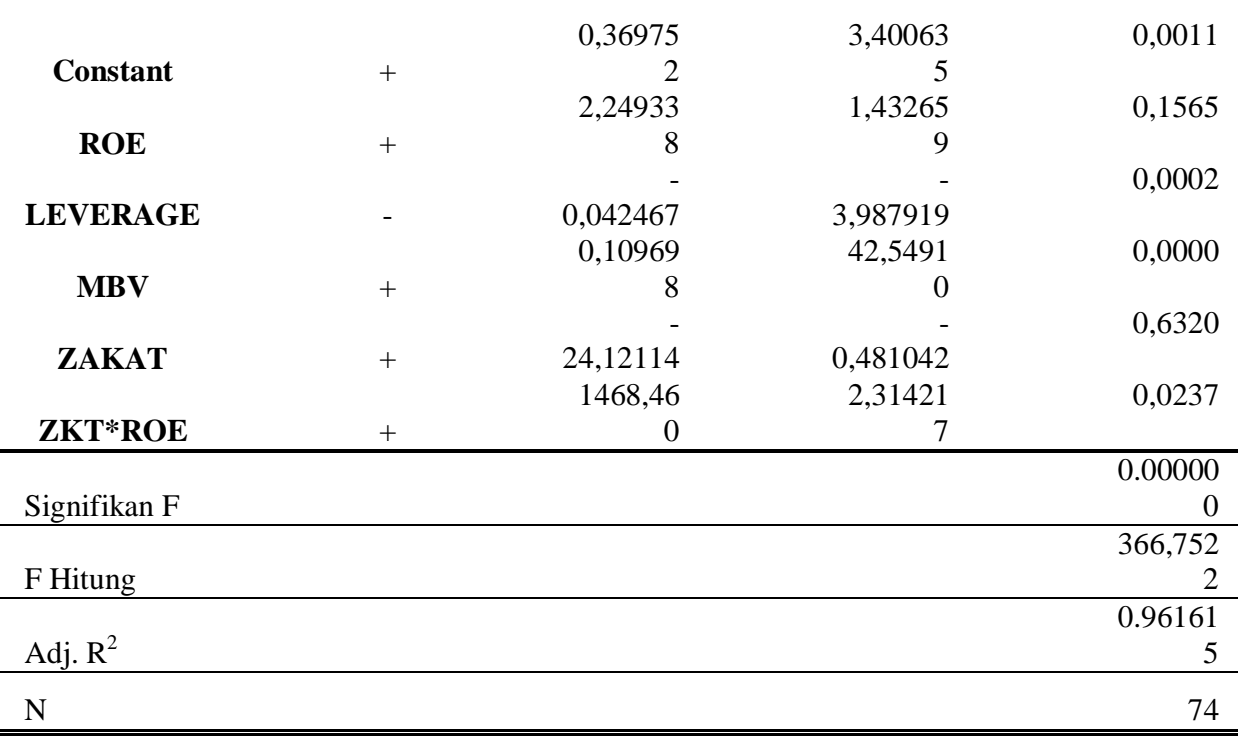

Table 2. Results of Regression on Company Performance on Firm value with Zakat as a Moderating Variable

These results also showed that zakat was not a moderator in the relationship between ROA and financial performance (ROA) and firm value (Tobins' Q), despite showing a positive effect. Disclosure of zakat did not effect the relationship between financial performance and firm value. This is also consistent with the results of a study by Suprantiningrum [16] who researched CSR disclosure as a moderator in the relationship between financial performance (ROE) and firm value (Tobins' Q). The results of that study showed that disclosure of CSR did not effect the relationship between financial performance and firm value in 66 manufacturing companies listed in the Indonesian Stock Exchange for the period of 2010-2012. In this case, zakat is considered a form of CSR (company social responsibility).

The results of this research showed empirical evidence that both supported and did not support some existing theories and research. Empirical evidence in support of previous research and theory was Leverage and Market to Book Value (MBV). Both Leverage and MBV each had significant effect on firm value. Company performance, or ROA in this case, did not have a significant positive effect on firm value. As for variables that have never been examined before, i.e. zakat, there is empirical proof that it has no significant positive effect on firm value and can not act as a moderating variable in the relationship between company performance (ROA) and firm value.

One of the factors behind why zakat can not act as a moderator in the relationship between profitability and firm value is that ROA has no significant effect on firm value even though testing without moderation yielded a positive coefficient in line with expectations.

\section{Conclusion}

This research resulted in the following conclusions:

1) Profitability indicated by ROA has a significant positive effect on firm value (Tobin's Q) when tested together with zakat.

2) Zakat has a significant positive effect on firm value. 
3) Profitability indicated by ROA using zakat as a moderating variable does not have a significant positive effect on the value of the company represented by the Tobin's $\mathrm{Q}$.

\section{References}

[1] M. H. Miller and F. Modigliani, "Dividend policy, growth, and the valuation of shares," J. Bus., vol. 34, no. 4, pp. 411-433, 1961.

[2] W. Sucuahi and J. M. Cambarihan, "Effect of Profitability to the Firm Value of Diversified Companies in the Philippines," Account. Financ. Res., vol. 5, no. 2, 2016.

[3] Y. Handoko, Pengaruh Kinerja Keuangan Terhadap Nilai Perusahaan Dengan Pengung-kapan Corporate Social Responsibility dan Good Corporate Governance sebagai Variabel Pemoderasi. Jakarta: Fakultas Ekonomi, Universitas Gunadarma, 2011.

[4] R. A. Sari, "Pengaruh karakteristik perusahaan terhadap corporate social responsibility disclosure pada perusahaan manufaktur yang terdaftar di bursa efek Indonesia," Nominal, Barom. Ris. Akunt. dan Manaj., vol. 1, no. 2, 2012.

[5] W. Yuniasih, "Pengaruh Kinerja Keuangan Terhadap Nilai Perusahaan Dengan Pengungkapan CSR dan Good Corporate Govemnance Sebagai variabel Moderating," in Simposium Nasional Akuntansi XII, 2009.

[6] M. L. Hadianto, "Analisis Pengaruh Kinerja Keuangan Terhadap Nilai Perusahaan dengan Pengungkapan CSR dan GCG sebagai Variabel Pemoderasi," Skripsi. Fak. Ekon. dan Bisnis. Semarang Univ. Diponegoro.eprint, 2013.

[7] U. Wahyudi and H. P. Prasetyaning, "Implikasi Struktur Kepemilikan Terhadap Nilai Perusahaan: Dengan Keputusan Keuangan Sebagai Variabel Intervening," in Proceeding Simposium Nasional Akuntansi IX, 2006, pp. 23-26.

[8] A. Azwar, "Pengaruh Faktor Fundamental Keuangan terhadap Risiko Sistematik pada Perusahaan LQ45 yang Tercatat di Bursa Efek Indonesia," in Seminar Nasional Akuntansi Vokasi V. Makassar: 12-14 Mei 2016., 2016.

[9] R. A. Agustina, "Faktor-Faktor Yang Mempengaruhi Pengungkapan CSR Pada Perusahaan Perbankan Konvensional Yang Terdaftar Di Bursa Efek Indonesia," Universitas Muhammadiyah Surakarta, 2013.

[10] V. Herawati, "The role of corporate governance practices as a moderating variable to the effect of earning management to firm value," in National Symposium on Accounting XI Pontianak, 2008.

[11] F. Tjiptono, "KEWIRAUSAHAAN, KINERJA KEUANGAN, DAN KELANGGENGAN BISNIS,” J. Manaj. Indones., vol. 15, no. 1, p. 17, Apr. 2017.

[12] Martono and A. Harjito, Manajemen Keuangan. Yogjakarta: Penerbit Ekonisia, 2008.

[13] Muhamad, Manajemen Keuangan Syari'ah: Analisis Fiqih dan Keuangan. Yogyakarta: UPP STIE YKPN, 2014.

[14] B. Susanti, "Pengaruh Locus Of Control, Equity Sensitivity, Ethical Sensitivity Dan Gender Terhadap Perilaku Etis Akuntan (Studi Empiris Kantor Akuntan Publik Wilayah Padang dan Pekanbaru)," J. Akunt., vol. 2, no. 3, 2014. 
[15] A. Chariri, Teori Akuntansi. Semarang: Badan Penerbit Universitas Diponegoro, 2007.

[16] Suprantiningrum and Sabat Nugroho Asji, "Pengaruh Moderasi Pengungkapan Corporate Social Responsibility (CSR) dan Good Corporate Governance (GCG) terhadap Hubungan Return on Equity dan Nilai Perusahaan," Serat Acitya, vol. 2, no. 3, p. 3, 2013. 